\title{
"Are key market players in currency derivatives markets affected by financial conditions?"
}

\begin{tabular}{|c|c|}
\hline AUTHORS & Ikhlaas Gurrib id https://orcid.org/0000-0001-8393-9790 \\
\hline ARTICLE INFO & $\begin{array}{l}\text { Ikhlaas Gurrib (2018). Are key market players in currency derivatives markets } \\
\text { affected by financial conditions?. Investment Management and Financial } \\
\text { Innovations, } 15(2), 183-193 \text {. doi: } 10.21511 / \text { imfi.15(2).2018.16 }\end{array}$ \\
\hline DOI & http://dx.doi.org/10.21511/imfi.15(2).2018.16 \\
\hline RELEASED ON & Monday, 04 June 2018 \\
\hline RECEIVED ON & Monday, 23 April 2018 \\
\hline \multirow[t]{2}{*}{ ACCEPTED ON } & Monday, 28 May 2018 \\
\hline & $(\mathrm{cc})$ EY-NO \\
\hline LICENSE & $\begin{array}{l}\text { This work is licensed under a Creative Commons Attribution-NonCommercial } 4.0 \\
\text { International License }\end{array}$ \\
\hline JOURNAL & "Investment Management and Financial Innovations" \\
\hline ISSN PRINT & $1810-4967$ \\
\hline ISSN ONLINE & $1812-9358$ \\
\hline PUBLISHER & LLC “Consulting Publishing Company "Business Perspectives" \\
\hline FOUNDER & LLC "Consulting Publishing Company "Business Perspectives" \\
\hline
\end{tabular}

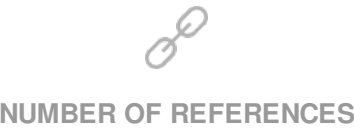

46

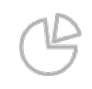

NUMBER OF FIGURES

2

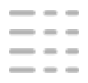

NUMBER OF TABLES

1

(C) The author(s) 2023. This publication is an open access article. 


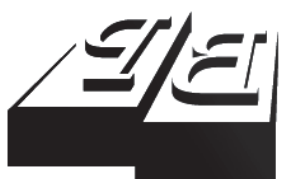

BUSINESS PERSPECTIVES

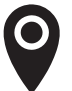

LLC "CPC "Business Perspectives" Hryhorii Skovoroda lane, 10, Sumy, 40022, Ukraine

www.businessperspectives.org

Received on: $23^{\text {rd }}$ of April, 2018 Accepted on: $28^{\text {th }}$ of May, 2018

(C) Ikhlaas Gurrib, 2018

Ikhlaas Gurrib, Associate Professor, Head of Accounting and Finance, Faculty of Management, Canadian University Dubai, UAE.

\title{
ARE KEY MARKET PLAYERS IN CURRENCY DERIVATIVES MARKETS AFFECTED BY FINANCIAL CONDITIONS?
}

\begin{abstract}
This study investigates if the biggest players in major foreign currencies futures markets are affected by current and previous financial conditions. Using root mean squared errors (RMSE), normalized RMSE, and Nash-Sutcliffe efficiency, this study compares the impact of current, 1 and 2 week lags of financial conditions onto foreign currency futures players' net positions. The financial conditions indices used are UFCI, STLFSI, NFCI and ANFCI with weekly data set from January 2007 till December 2018. The US dollar index futures is included as a benchmark, since the financial conditions are based on US data and the most actively traded foreign currencies are paired against the USD. While RMSE and NRMSE gave mixed results into how current, 1 week and 2 weeks lagged Financial Conditions Indices (FCIs) values are related to speculators and hedgers' net positions, lagged NFCI captured the highest correlation with both players' net positions in Japanese Yen. 95\% prediction levels encompassed the actual net positions held, including the financial crisis of 2008-2009. Forecasts were lower (higher) for hedgers (speculators) than actual net positions held during the same period. Comparatively, in the period 2016-2017, hedgers (speculators) net positions forecasts were higher (lower) than actual positions. The latter could be explained by FCIs not being affected during this period's event, compared to net positions. While net positions data were stationary, excess kurtosis was present pointing to non-normal and autocorrelated series. This suggests the need to look into other components like non-reportable long or short positions in future analysis.
\end{abstract}

Keywords

\section{JEL Classification F31, G15, G18}

\section{INTRODUCTION}

As part of its mission of assuring transparent, competitive and above all stable derivatives markets, the Commodity Futures Trading Commission (CFTC) has a critical role in the US futures markets by providing succinct public information towards the aim of reducing the risk involved in managing futures contracts. To that effect, key market players' transactions in the US futures markets have been historically captured by the CFTC as either non-commercial or commercial traders, where they represent the largest speculators and hedgers holding positions above reporting levels set by the CFTC. For instance, Klitgaard and Weir (2017) found a strong relationship between speculators' net positions and weekly exchange rate movements of six major foreign currencies paired against the USD. Early studies like Gurrib (2009) used GARCH and PARCH models to assess the predictability of hedgers and speculators' positions on 29 futures markets, and found models used to be poor predictors of 1-month return. The same study also found currency futures to be non-normal, more volatile than equity index futures, but have volatility decaying over time. Similarly, 
Gurrib (2008) analyzed the effect of major global events on speculators and hedgers' net positions, and found any significant structural break was short-lived. These studies, particularly the last one, suggest that the relationship between financial conditions, which affects global markets and futures markets key market players' actions, need to be further understood, since it can provide invaluable information related to policy and risk assessment. For instance, Dudley (2010) and Koop and Korobilis (2014) found financial conditions information to be helpful in assessing the linkages between reported financial markets, economic activity and policies.

Studies focusing on the relationship between financial conditions and the foreign currency futures markets are quite scarce. Gurrib (2018a) proposed a unified condition index and compared its predictability in the most actively traded USD paired foreign currencies, using root mean squared errors, and Gurrib (2018b) allowed for some comparison in the forecasts errors with the normalized root mean squared errors and the Nash-Sutcliffe coefficients. While Gurrib (2018a) found major financial condition indices to be poor predictors of foreign currency spot values, Gurrib (2018b) reported the St Louis Federal Financial Condition Index (STLFSI) to forecast higher than actual values for AUD/USD and CAD/USD in the 2008-2009 global financial crisis, and vice versa during the 2000-2002 technology bubble. One important distinction in the latter two papers resides in that Gurrib (2018a) proposed a unified condition index which is based on various FCIs, while Gurrib (2018b) focused only on the STLFSI.

This study contributes to existing literature on various grounds. Firstly, while there are some studies in the area of equity markets and foreign currency spot markets and financial conditions, the relationship between futures markets and financial conditions is scarce. This is the first study to analyze if the largest speculators and hedgers net positions are affected by previous financial conditions. The six most actively traded foreign currency futures markets are assessed together with the US dollar index futures. The implication of this paper is important in that it reveals whether the biggest players (speculators, hedgers or both) in the futures markets are affected by current or previous financial conditions. This provides further guidance to regulatory bodies such as the Commodity Futures Trading Commission (CFTC) in its mandate towards ensuring greater price stability in the futures markets. The rest of the paper provides some literature review, followed by the research methodology and data section. Some descriptive statistics and forecasting results are reported before providing some conclusive remarks.

\section{LITERATURE REVIEW}

Rey (2013) supported that the effect of globalization and reliance on purely domestic policies led national policy makers to consider global factors when assessing each country's financial stability/ conditions and subsequent developments. Further, policymakers are not the only drivers of financial disruptions. Changes in market uncertainty, bailouts or rumors on corporate transactions, and changes in the sentiment of investors caused by unconventional events, can all influence financial markets, which in turn affect asset prices, firm's value and ultimately economic performance. IMF (2017) reported that around 20 to 40 percent of changes in financial conditions indices (FCIs) can be attributed to global financial conditions, where one factor, which is correlated with the Chicago Board Options Exchange (CBOE) volatility in- dex indicator (VIX), tends to be the main driver. Adrian, Boyarchenko, and Giannone (2016) found that FCIs can be used to predict following economic retrenchments. Schoenmaker (2013) pursued that the implementations of effective policies aimed at financial stability is vital in an open economy. Calvo, Leiderman, and Reinhart (1996), Bruno and Shin (2013), IMF (2014), and Baskaya et al. (2017) are all proponents that financial measures like VIX are important drivers of financial conditions.

While studies like Gumata, Klein, and Ndou (2012) constructed FCIs for specific countries using global factors like S\&P500 volatility index, S\&P 500 market index values, and the three month LIBOR, US regulatory based FCI models like those from $\mathrm{St}$ Louis Fed Reserve, Chicago Fed Reserve are more popular. Aramonte, Rosen, and Schindler (2017) 
found various FCIs are able to predict S\&P 500 quarterly and monthly based returns. They also support that despite some methodological differences in FCI constructions, they exhibit a large amount of common variability due to the fact that changes in the financial system affect many of the variables under most FCIs. Despite the fact that FCIs tend to share similar long-run movements, they can nonetheless provide different financial conditions values. Even if methodologies involved in constructing FCIs vary considerably, they are mostly based on financial market variables like treasury yields, stock market return, and implied volatilities. The study carried by Kliesen, Owyang, and Vermann (2012) give a good overview of the variables used in major financial conditions indices in the US.

The prominence of financial stability is highlighted by the results in many studies. For instance, a contractionary credit supply policy eventually can affect investing opportunities as laid out in Campello, Graham, and Harvey (2010) and the wider economy (see for example Calomiris \& Mason, 2003; Peek \& Rosengren, 2000). Hakkio and Keeton (2009) captured the characteristics around financial stress, which is conceptualized as a disruption to the normal functions of financial markets. While each period of financial stress is different in nature, they note important common characteristics based on the increase in uncertainty in the intrinsic values of assets, lack of confidence on the behavior of other traders, increased asymmetric information, an increased inclination to invest in less risky and more liquid assets. While it is accepted that the value of an asset today is based on time adjusted expected future cash flows, financial stress results in volatility in different asset classes. Uncertainty in these cash flows can arise from uncertainty in future economic conditions or complex products, which are difficult to value. The heightened volatility is a consequence of investors over/under reacting to new information, as propelled by Hautsch and Hess (2007) and Pastor and Veronesi (2008).

Similarly, uncertainty about the behavior of other investors can be explicated by lenders and investors relying on their random guess about other investors' decisions instead of relying on fundamentals, which eventually lead to more volatility in prices. The increase in asymmetric information can be substantiated with lenders having difficulty in determining the true quality of borrowers and also through investors losing confidence on the quality of issuers' credit ratings. Further, a shift towards quality, as opposed to risk, during financial stress, leads to a move of investors toward safer assets, where safer assets would be expected to yield a lower return than riskier ones. As propelled by Caballero and Kurlat (2008), this is habitually accompanied by an increase in borrowing costs for the more risky borrowers, and mostly a manifestation of investors and lenders to overestimate risk during economic bubbles (Guttentag \& Herring, 1986). Alternatively stated, issuers of illiquid assets bear the higher cost of borrowing during financial stress periods, in order to compensate investors for the higher risk of not selling their assets.

Existing literature covers extensively transmission channels across markets and economies with a lot of focus on monetary independence in setting interest rates. Factors such as foreign exchange movements usually lead to significant changes in financial conditions in small economies opened to trade, as reported in Kearns and Patel (2016). Other cross border effects include changes in credit volumes and co-movements in risk premiums, which can affect valuation (Obstfeld, 2015). IMF (2017) suggests that integrated financial markets, on a global scale, can obfuscate the management of local financial conditions, especially where countries have united with the global economy, recommending the need for policymakers to consider external factors when pursuing domestic objectives. While IMF and OECD construct and analyze country based FCIs, financial conditions, on an international basis, are generally led by the US, which is the key country in the international monetary system. Rey (2013) reported that the average correlation between major US FCIs and measures of global financial conditions and the VIX to be around 80 percent. IMF (2014) further adds that the US dollar resides as a global currency with crucial roles in the issuance of financial assets and trading of commodities, under the oversight of regulatory bodies such as the CFTC.

While the essence of financial stability is made clear, it is important to understand that FCIs have been constructed using various ways like vec- 
tor auto regressive models (VARs) and impulse functions (Swiston, 2008) and principal component analysis (PCA). Since this study makes use of the latter method, an overview of FCI using PCA is warranted. For instance, Montagnoli and Napolitano (2005) used Kalman filtering algorithm for capturing the weight changes of financial variables in the explanation of the output gap, and constructed the FCI of the Canada, United States, the Euro zone and the United Kingdom. Swiston (2008) used impulse response functions to build the FCI of the United States and suggested that FCI could predict the United States' real GDP growth. Hatzius (2010) used the principal component analysis method to select the first principal component as the FCI and forecast economic growth by using FCI. Gomez (2011) constructed an FCI based on financial markets for Colombia using PCA and found the FCI to be a better predictor of GDP growth than an autoregressive model of the GDP growth itself. Further, the FCI was tested in its ability to anticipate future financial stress periods, and concluded it could be used as an indicator giving early warnings of destabilization in financial stability.

\section{RESEARCH METHODOLOGY}

Previous studies like IMF (2017) used quarterly and monthly based forecast models to reduce the possibility that predictions include business cycle effects. With many FCIs consisting of the volatility Index measure (VIX), Bollerslev, Tauchen, and Zhou (2009) concluded that the difference between a measure of realized variance and the squared value of CBOE's VIX, help in forecasting equity returns for the next three to six months, with $r$-squared values slowly declining at longer horizons. English, Tsatsaronis, and Zoli (2005) who relied on higher data frequencies find aggregated financial variables as a proxy for financial condition to have some predictive power for macroeconomic variables. However, Hatzius et al. (2010) find FCIs to be less useful as early warning indicators, similar to Aramonte, Rosen, and Schindler (2017) who used monthly and quarterly horizons.

Further, while some daily FCIs exist, such as the Bloomberg US FCI and the Morgan Stanley FCI, the Cleveland FCI which was based on a daily fre- quency was discontinued in May 2016. While the choice of weekly based FCIs reduce the number of potential FCIs under analysis, it is important to understand what's included in these FCIs before utilizing them in the principal component analysis. These mostly include interest rate spreads which captures risk premium, term premium and liquidity premium; stock market, foreign exchange and volatility indicators, and yields to maturity. Kliesen, Owyang, Vermann (2012) provides an overview of the different variables falling under each category, suggesting that the overlap across the various condition/stress indexes is quite substantial as expected. Lastly, but not least, while some authors like Carlson, Lewis, and Nelson (2012), and Louzis and Vouldis (2011) differentiate between financial condition index and financial stress index (FSI), this paper does not discriminate between them due to the high correlation observed among major US based FCIs and FSIs. Although Hatzius and others (2010) and the Federal Reserve Bank of Chicago made use of more than forty five and one hundred variables, Boivin and $\mathrm{Ng}(2006)$ pointed out that the inclusion of more data does not necessarily produce better results. This is further supported by Lo Duca and Peltonen (2011) who argue that adding more redundant variables may not improve an FCI, and Grimaldi (2011) who find that too many variables can potentially exacerbate to more false periods of high stress in the markets. This study makes use of the different financial conditions indices as reported by the different Federal Reserve bodies.

The methodology is centered upon testing the forecasting ability of the different FCIs (UFCI, STLFSI, NFCI, ANFCI) over net positions of both hedgers and speculators, using current, 1 week and 2 week lagged values, under an ordinary least squares framework. Root mean squared errors and normalized root mean square errors are used as forecasting measures. The models are robust tested for normality, white noise and stationarity. The rest of the paper provides the data section, followed by the research findings and conclusive remarks.

\section{DATA}

The Commodity Futures Trading Commission (CFTC) classifies information obtained from Form 40, with traders who manage their busi- 
Table 1. Contract specifications

\begin{tabular}{|c|c|c|c|c|c|}
\hline Market & ISO code & Exchange & Contract size & $\begin{array}{c}\text { Reportable } \\
\text { positions/Open } \\
\text { interest, \% }\end{array}$ & $\begin{array}{c}\text { Net positions } \\
\text { correlation } \\
\text { coefficients, \% }\end{array}$ \\
\hline Canadian Dollars & $\mathrm{CAD}$ & CME & 100,000 CAD & 75.3 & -95.40 \\
\hline Swiss Francs & $\mathrm{CHF}$ & $\mathrm{CME}$ & $125,000 \mathrm{CHF}$ & 74.8 & -93.6 \\
\hline British Pounds & GBP & $\mathrm{CME}$ & $62,500 \mathrm{GBP}$ & 85.2 & -98.3 \\
\hline Japanese Yen & $\mathrm{JPY}$ & $\mathrm{CME}$ & $12.5 \mathrm{~m} \mathrm{JPY}$ & 87.3 & -97.8 \\
\hline EUR & EUR & $\mathrm{CME}$ & 125,000 EUR & 82.9 & -99.5 \\
\hline Australian Dollar & AUD & $\mathrm{CME}$ & 100,000 AUD & 79.9 & -99.2 \\
\hline US dollar index & USDX & ICE & US dollar index * $\$ 1000$ & 87.7 & -99.4 \\
\hline
\end{tabular}

Note: CME is the Chicago Mercantile Exchange and ICE is the Intercontinental Futures Exchange.

ness risks by hedging in futures being classified as commercials, and the rest as non-commercials (CFTC, 2018). While the classification is continuously under review by CFTC, our study adopts a similar approach, where net positions of hedgers (speculators) are calculated by taking the difference between commercial (non-commercial) long positions and commercial (non-commercial) short positions. The currency futures markets under analysis include futures contracts in Canadian Dollar, Swiss Francs, British Pounds, Japanese Yen, Euro, Australian dollar and US dollar index. The four FCIs under study includes the STLFSI which is the weekly St Louis Fed Financial Stress Index; the Unified FCI (UFCI) as proposed by Gurrib (2018a); Chicago's National FCI (NFCI) and the Adjusted NFCI (ANFCI). While the Commitment of Traders (COT) data are available from 1962, the weekly data have been available from 2000 . Essentially, every Friday, the COT reports provide a decomposition of every Tuesday's open interest in specific futures markets where twenty or more traders hold positions equal to or above reporting levels set by CFTC. The Open Interest $(O I)$ calculated as follows:

\section{OI $=$ Total reportable positions + \\ + Total non reportable positions,}

Total reportable positions $=$

$=$ Commercial long (Short) positions +

+ Non commercial long (Short) positions +

+ Net non-commercial spread.

The analysis is conducted over the period from January, 3, 2007 till January 23, 2018, and all data are collected from the St Louis Federal Reserve database (FRED) and the CFTC.

\section{RESEARCH FINDINGS}

Table 1 provides a summary of the foreign currency futures under analysis, including their contract specifications, the proportion of reportable positions relative to open interest, and the correlation coefficients of hedgers and speculators' net positions. As observed, the reportable positions represents a significant portion of the total open interest in the most actively traded foreign currency futures, with a range of 75.3-87.7\%. The largest hedgers and speculators share a strongly negative correlation across all currencies with correlation coefficients near -1 . The US dollar index futures shared the highest reportable positions to OI ratio and the most negative correlation between the net positions of speculators' and hedgers.

Figure 1 captures the relationship between net positions of the largest speculators and largest hedgers. While the negative relationship between the net positions between hedgers and speculators is consistent with the strongly positive correlations observed in Table 1, the period 2008-2009, which witnessed the global financial crisis, had the lowest net positions for both players. All futures speculators, except for the Japanese Yen and US dollar index, were net long during the September 2008 Lehman Brothers crash. Similarly, hedgers in the two futures markets were net long. More importantly, the fluctuations in the net positions for both players appear to be greater in other periods compared to the September event time. Keeping in mind that net positions is the difference between long and short positions, a higher non-absolute value in net position, whether for hedgers or speculators, can be attributed to a widened gap within long and short positions by the hedgers or speculators. Alternatively stated, a high net po- 
sition value for hedgers will mostly be accompanied by an opposite high net reportable position for speculators in the that specific futures market. Due to the highly negative correlation between the two players, and the fluctuations of net reportable positions, this study would analyze the effect of financial conditions for both key market players.

In line with Gurrib (2018a) who proposed the UFCI index, which is based on principal component analysis, BIS (2016) and Gurrib and Kamalov (2018) who reported that the top five most active currencies during 2013 and 2016 were the USD, EUR, JPY, GBP and the AUD, this study analyzes the impact of UFCI, STLFSI, NFCI and ANFCI onto the six major foreign currency futures, including the US dollar index futures. The inclusion of the US dollar index is beneficial, since all the FCIs are heavily tilted on US data, and the major currencies under analysis form the most actively traded foreign currencies, when paired against the USD. When paired against the USD, they represent 87 and 88 per cent of all OTC foreign exchange transactions during 2013 and 2016 (BIS, 2016). To test for the importance of financial conditions onto net positions of hedgers and speculators, the following model is used:

$$
N P_{t}^{h, s}=\alpha+\beta \cdot F C I_{t-1}+\varepsilon_{t},
$$

where $h$ and $s$ represent the hedgers and speculators net positions and $F C I_{t-1}$ represents the financial conditions indices lagged by 1 week and 2 weeks, where FCI include the UFCI, STLFSI, NFCI and ANFCI indices. Current FCI values are also regressed against current NP for comparison purposes. The lagged and current FCIs is regressed against the specific players' net positions, one at a time. Both the root mean squared errors (RMSE) and normalized RMSE (NRMSE) are used to account for the relative difference in the units of foreign currencies, where the latter is calculated as follows:

$$
N R M S E=\frac{R M S E}{F C I_{o b s, \text { max }}-F C I_{o b s, \text { min }}} .
$$

This allows for a better comparison among currencies. Due to the high correlation observed between UFCI, STLFSI, NFCI and ANFCI in Gurrib (2018a), the root mean square errors and normalized forecast values under each of the FCI mod- els are calculated for both hedgers and speculators. Although not reported here, while the UFCI failed to best forecast the net positions of the next periods, the NFCI yielded the smallest RMSE for CHF, JPY, GBP and AUD when the condition index is lagged by 2 and 1 week, respectively. The STLFSI produced the smallest RMSE for the US dollar index futures when the former is lagged by 1 week. Similarly, the use of a 2 week lagged ANFCI yielded the lowest RMSE for CAD and EUR. The use of current FCIs did not help in explaining the net positions held by speculators in these foreign currency futures markets. The normalized RMSE showed different results compared to the RMSE. The use of UFCI with two lags produced the lowest NRMSE values for CHF. Speculators' net positions in the EUR had the highest NRMSE compared with the other currency futures. Only the CAD current UFCI values helped in explaining current net positions for speculators. The use of 1 week lag for UFCI helped in forecasting the speculators' net positions for the AUD. Similar results were observed for hedgers where RMSE were the lowest mostly under the NFCI, for CHF, GBP and JPY. 2 weeks lagged UFCI, STLFSI and ANFCI values produced the lowest RMSE for AUD, US Dollar Index, and CAD and EUR respectively. NRMSE values were the lowest under the UFCI compared with other FCIs. While CHF had the lowest NRMSE compared with other foreign currency futures net positions, with the exception of JPY, which used 1 week lag, the use of 2 week lagged values produced the lowest NRMSE. More importantly, the NRMSE for all speculators' net positions were lower than those of hedgers, suggesting that the model in use is a better predictor of speculators' net positions.

With different financial conditions reporting different forecasting errors for different futures markets under different lag settings, it is critical to keep track of the relationship between financial conditions indices and the net positions of speculators and hedgers. For the purpose of conciseness, only the futures markets with the highest correlation coefficients are reported here. Using current, 1 and 2 week lagged FCIs, the NFCI yielded the highest correlation coefficient values of 0.53 for speculators' net positions in Japanese Yen. For the same currency, all other FCIs reported low correlation coefficients ranging from 0.43- 
Canadian Dollar

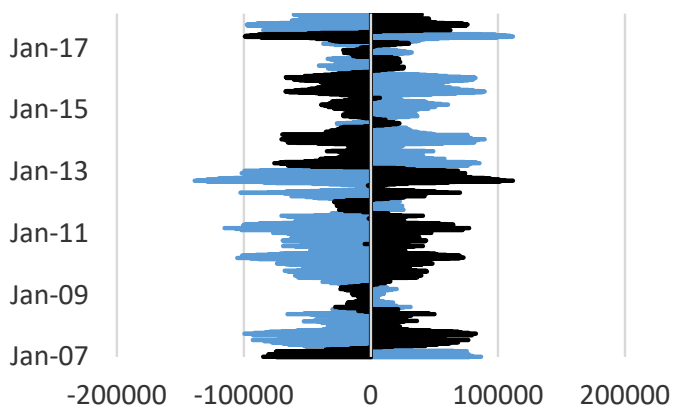

British Pounds
Jan-17

Jan-15

Jan-13

Jan-11

Jan-09

Jan-07

$-200000$

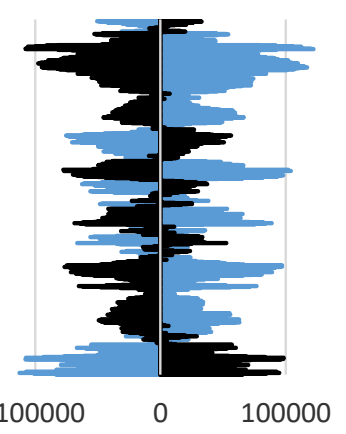

Jan-17
Jan-15
Jan-13
Jan-11
Jan-09
Jan-07

$-400000$
Euro

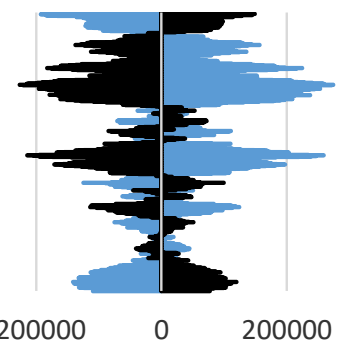

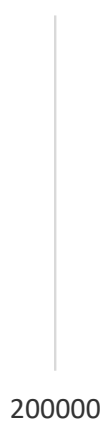

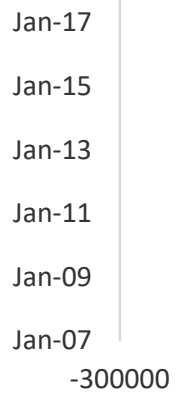

Swiss Francs

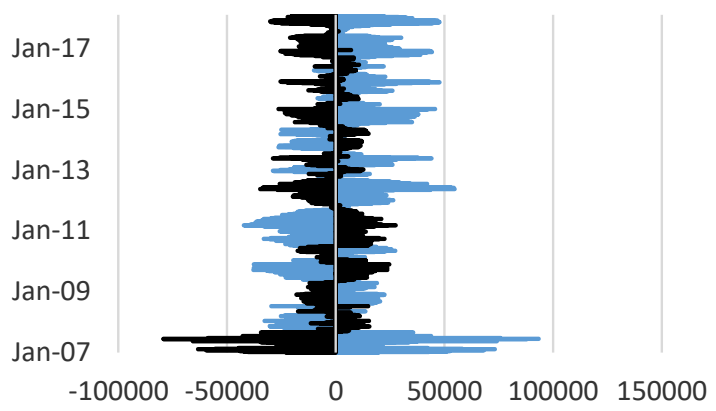

Japanese Yen

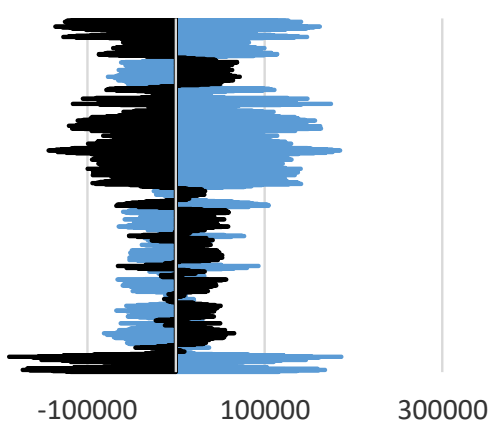

Australian dollar

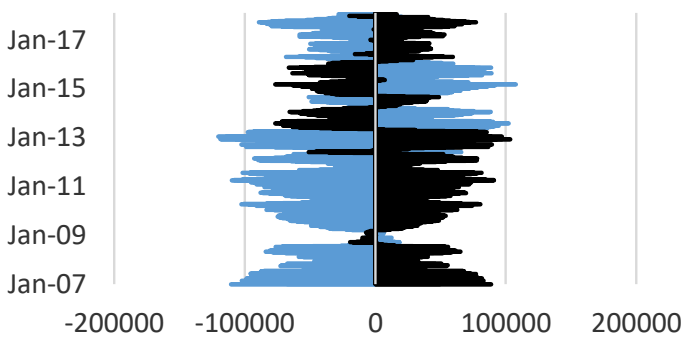

US dollar index

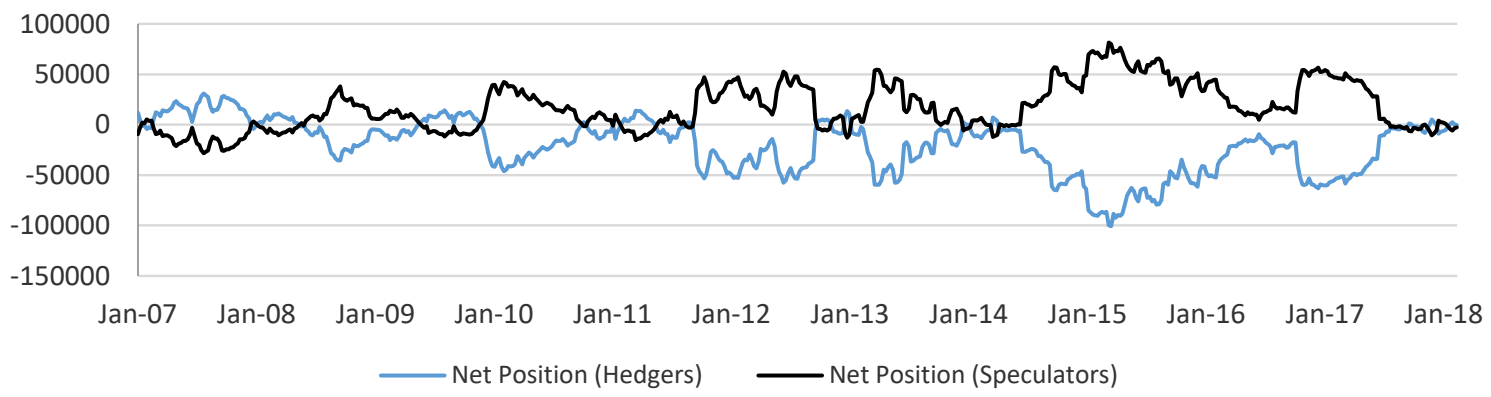

Figure 1. Net positions in major foreign currencies futures

0.48 , under different lags. For other futures markets under study, the correlation coefficients FCIs and speculators' net positions ranged from -0.25 to 0.19 . Comparatively, hedgers' net positions and FCIs shared more negative correlations, where the use of NFCI reported the highest negative value of -0.57 for Japanese Yen futures. For the other currency futures under study, values ranged from -0.22 to 0.31 across all FCIs.

To evaluate the efficiency of the relationship between net positions for hedgers and speculators 
in Japanese Yen futures and the NFCI, the NashSutcliffe efficiency coefficient $(E)$ is calculated, where values can fluctuate between $-\infty$ to 1 (Nash \& Sutcliffe, 1970). While a value of $1(E=1) \mathrm{im}$ plies an exact match between the observations and the model, a value of 0 suggests that the model predictions are as precise as the average of the data. An efficiency value of less than zero is possible when the average is a superior predictor than the current model used.

$$
E=1-\frac{\sum_{t=1}^{n}\left(F X_{o b s, t}-F X_{\text {fitted }}\right)^{2}}{\sum_{t=1}^{n}\left(F X_{o b s, t}-\overline{F X}_{o b s, t}\right)^{2}},
$$

where $F X_{\text {obs }, t}$ are observed values of the foreign currencies net positions and $F X_{\text {fitted }}$ are the forecasted values at time $t$. Zero values of $F$ for speculators and hedgers based models suggest that the estimated results are not based on randomness. The zero p-values of the NFCI coefficients are zero as well, suggesting that the financial condition index is a reliable factor in determining the value of the Japanese Yen speculators and hedgers' net positions. The residual variance from the forecast model for both players' net positions were relatively lower than the variance in the observed net positions, leading to a Nash-Sutcliffe efficiency coefficient of 0.3226 and 0.2795 for hedgers and speculators respectively. The $r$-squared values for both remain low, where only $32 \%$ and $28 \%$ of the variability in hedgers and speculators net positions can be explained by the 2 weeks and 1 week lagged FCI values. To explain the low $r$-squared values and fully assess the use of financial condition index variable in predicting foreign currency pair values, it is important to compare the actual values with the one based on the forecasted (fitted) model.

Assuming that at a fixed value of financial condition index, the distribution of points about the true regression line follows a normal distribution and it is centered on the regression line, a 95\% prediction interval is calculated as: Net positions forecasted values \pm 2 . RMSE. As observed in both Panels A and B of Figure 2, the forecasted net positions were, on average, close to the actual values, except during periods of crisis. The residual plots from Panel A and B show an increase in the abso- lute gap between actual and forecasted values during the periods 2008-2009 and 2016-2017. While in the period 2008-2009, Panel A shows forecasts were lower for hedgers than actual net positions held, Panel B shows forecasted values for speculators were higher than actual values during the same period. Comparatively, in the period 20162017, hedgers net positions forecasts were higher than actual positions, and speculators' net positions were forecasted to be lower than actual net positions held. This can be explained by the fact that the FCI captured the 2008-2009 crisis movements, but failed to do so in the latter period, where it reported rather stable net position values. More importantly, the $95 \%$ prediction intervals for both hedgers and speculators' net positions resulted in a lower and upper band which includes the actual net positions values. Assuming a normal distribution, despite the $r$-squared values being quite low, the lower and upper bands of the prediction level tracked fairly closely to the actual net positions of hedgers and speculators. The residual plots, however, were tracking closely to the actual net positions data, suggesting the possibility of auto correlated data.

To validate the robustness of the model, the net positions for speculators and hedgers in the Japanese Yen futures markets are tested for stationarity, white noise, normality, and potential arch effects. Using variations such as constant, no constant, and constant and trend adjustments, both hedgers and speculators level data were found to be stationary at 5\% level. Using Ljung Box Q test, both speculators and hedgers' net positions data shows statistical evidence that the series are auto correlated, at $1 \%$ and $5 \%$ level. With an excess kurtosis of -1.37 and -1.05 , both the Jarque Bera and the Doornik Chi-square tests, rejected the normality assumption at both $1 \%$ and $5 \%$ level. This is consistent with findings of Gurrib (2009) who find excess kurtosis and non-normality presence. The ARCH effect test, which tests for potentially higher order autocorrelated data, supports the presence of time varying volatility for both speculators and hedgers net positions. While the series are stationary, the lack of normality and white noise series allows the predictive interval results only to hold assuming the net positions are normally distributed. This suggests the need to tap into other components of the open interest, instead of using net po- 
Panel A. Hedgers net positions

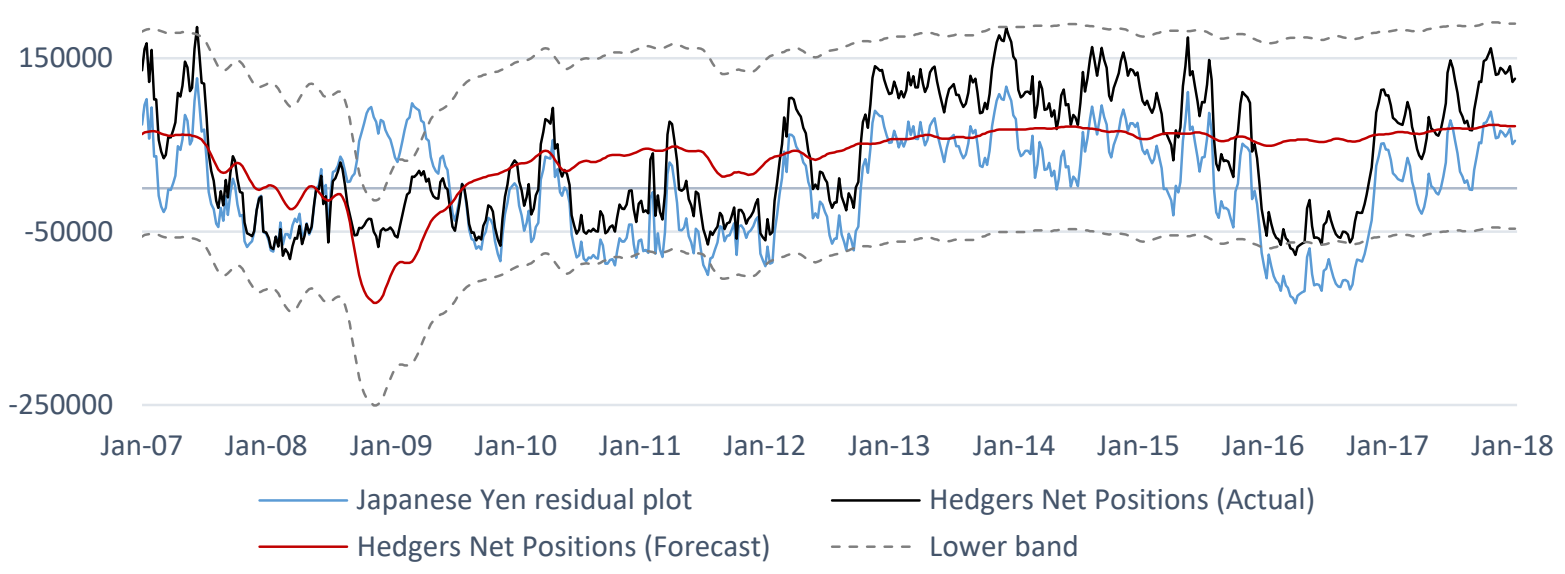

Panel B. Speculators net positions

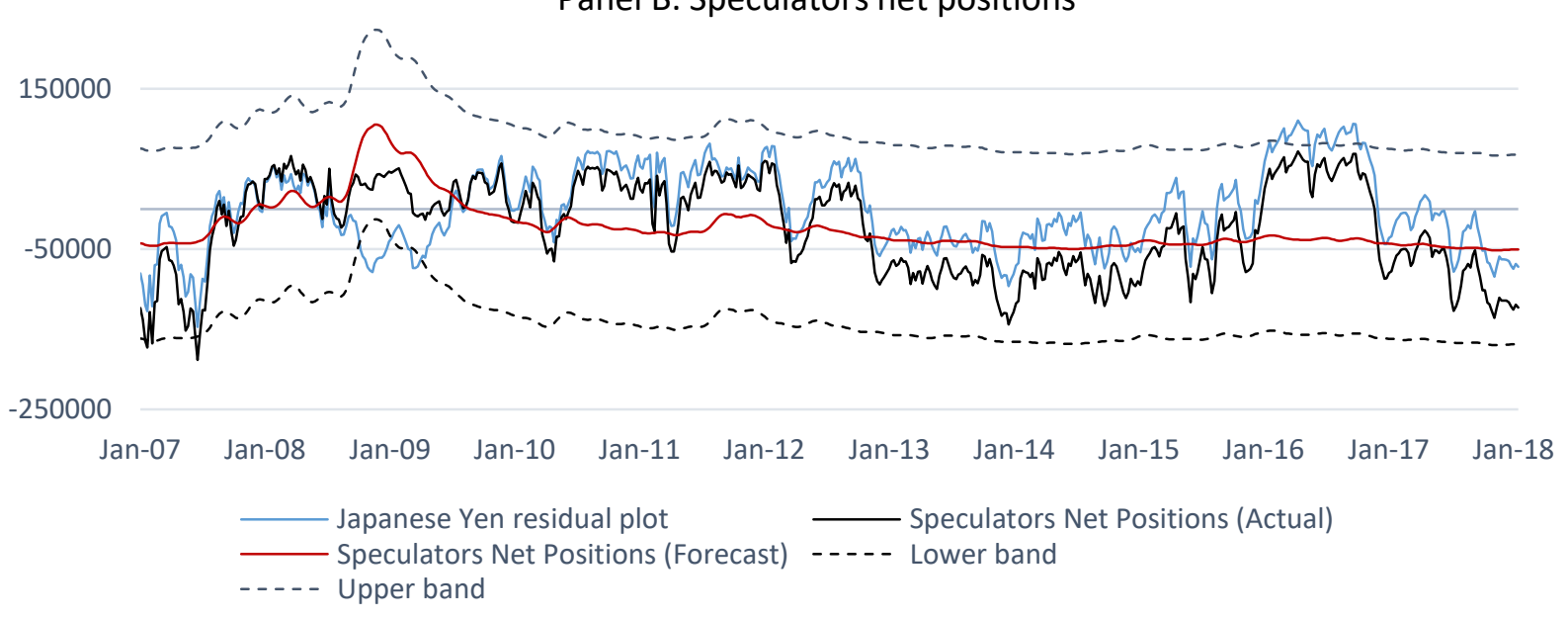

Figure 2. Japanese Yen hedgers and speculators net positions

sitions of key players as a forecasting variable. For -0.65 to -0.68 , using both current and 1 week instance, although not reported here, compared to all other components of open interest, the non- reportable short positions for Japanese Yen had the highest correlation coefficient with the four financial conditions indices under study, ranging from lagged FCI values. Although the change in non-reportable short positions also failed the normality test, it passed the white noise test, and ARCH effect test at the $5 \%$, making it a better candidate as a dependent variable for future research.

\section{CONCLUSION}

This paper has introduced some extra layer of information in terms of financial conditions and foreign currency futures markets. Regulatory bodies such as CFTC can benefit from it, in that it suggests some relationships between financial stability and activities in the futures market. This has some implications towards the mandate of promoting and ensuring stability in futures and spot markets. The main objective of this paper is to test if net positions of the largest speculators and hedgers in the most active foreign currency markets are affected by current, 1 week and 2 week lagged financial conditions. Using weekly data set over the period 2007-2018, this study used RMSE, NRMSE and the Nash-Sutcliffe efficiency coefficients to assess how net positions in the Australian and Canadian dollar, Euro, Japanese 
Yen, British Pounds, Swiss Francs are affected by current FCIs. The US dollar index futures is also included, since these currencies, when paired with the USD, form the most actively traded foreign currencies on OTC markets. The four FCIs in use are also based on US data. With low correlations detected initially between net positions and FCIs (current and lagged values), and RMSE/NRMSE showing mixed results, only the Japanese Yen was analyzed further, where the NFCI reported the lowest RMSE using 1 week lag for speculators and 2 weeks lag for hedgers' net positions. US Dollar Index futures net positions for both players showed the second highest correlations with the FCIs. 95\% lower and upper prediction bounds captured all the actual net positions held for both key market players. The model was, however, robust tested for normality, white noise and stationarity. While net positions for Japanese Yen were stationary at levels, excess kurtosis was present, which led the Jarque-Bera test to reject normality at $5 \%$ level. Similarly, ARCH effects were present suggesting time varying volatility. This suggests the need to look into other components of open interest like long or short non-reportable positions when analyzing the potential effects of financial conditions onto futures markets. Another potential avenue of future research might tap into using transformed or non-linear data.

\section{REFERENCES}

1. Adrian, T., Boyarchenko, N., \& Giannone, D. (2016). Vulnerable Growth (Federal Reserve Bank of New York Staff Report, September, No. 794).

2. Aramonte, S., Jahan-Parvar, M. R., Schindler, J. W., \& Rosen, S. (2017). Firm-Specific Risk-Neutral Distributions: The Role of CDS Spreads (FRB International Finance Discussion Paper, No. 1212).

3. Baskaya, Y. S., Giovanni, J. D., Kalemli-Ozcan, S., \& Ulu, M. F. (2017). International spillovers and local credit cycles. National Bureau of Economic Research, Cambridge, MA.

4. BIS (2016). Triennial Central Bank Survey Foreign exchange turnover in April 2016, Monetary and Economic Department. Retrieved from http:// www.bis.org/publ/rpfx16fx.pdf (accessed on September 28, 2017).

5. Boivin, J., \& Ng, S. (2006). Understanding and Comparing Factor-Based Forecasts. International Journal of Central Banking, 1(3), 117-51.

6. Bollerslev, T., Tauchen, G., \& Zhou, H. (2009). Expected Stock Returns and Variance Risk Premia. The Review of Financial Studies, 22(11), 4463-4492. http://dx.doi. org/10.1093/rfs/hhp008

7. Brave, S. A., \& Butters, R. A. (2012) Diagnosing the financial system: Financial conditions and financial stress. International Journal of Central Banking, 8(2), 191-239.

8. Bruno, V., \& Shin, H. S. (2013). Capital Flows and the Risk-Taking Channel of Monetary Policy (NBER working paper 18942).

9. Caballero, R. J., \& Kurlat, P. (2008). Flight to Quality and Bailouts: Policy Remarks and a Literature Review (Working Paper, October).

10. Calomiris, C. W., \& Mason, J. R. (2003). Fundamentals, Panics, and Bank Distress During the Depression. American Economic Review, 93(5), 1615-1647.

11. Calvo, G. A., Leiderman, L., \& Reinhart, C. M. (1996). Inflows of Capital to Developing Countries in the 1990s. Journal of Economic Perspectives, 10(2), 123-39.

12. Campello, M., Graham, J. R., \& Harvey, C. R. (2010). The Real Effects of Financial Constraints: Evidence from a Financial Crisis. Journal of Financial Economics, 97, 470-87.

13. Cardarelli, R., Elekdag, S., \& Subir, L. (2011). Financial Stress and Economic Contractions. Journal of Financial Stability, June, 7(2), 78-97.

14. Carlson, M., L. K., \& William, N. (2012). Using Policy Intervention to Identify Financial Stress. Finance and Economics Discussion Series No. 2012-02, Board of Governors of the Federal Reserve System. Retrieved from www.federalreserve.gov/pubs/ feds/2012/201202/201202pap.pdf (accessed on September 20, 2017).

15. CFTC (2018). Traders in Financial Futures: Explanatory Notes. Retrieved from http://www.cftc. gov/idc/groups/public/@commitmentsoftraders/documents/file/ tfmexplanatorynotes.pdf (accessed on February 2, 2018).

16. Dudley, W. C. (2010). Comments: Financial Conditions Indexes: A Fresh Look after the Financial Crisis. Remarks at the University of Chicago Booth School of Business Annual U.S. Monetary Policy Forum, New York, February 26

17. English, W., Tsatsaronis, K. and E. Zoli (2005). Assessing the predictive power of measures of financial conditions for macroeconomic variables. BIS chapter, 22, 28-52.

18. Gomez, E. (2011). Financial Conditions Index: Early and Leading Indicator for Colombia. Ensayos sobre Politica Economica, 66, 174-220.

19. Grimaldi, M. B. (2011). Up for Count? Central Bank Words and Financial Stress (Sveriges Riksbank Working Paper Series, 252, April 2011). Retrieved from www.riksbank.se/upload/Dokument_riksbank/Kat_publicerat/WorkingPapers/2011/wp252.pdf (accessed on November 12, 2017).

20. Gumata, N., Klein, N., \& Ndou, E. (2012). A Financial Conditions Index 
for South Africa (IMF Working Paper, WP/12/196).

21. Gurrib, I. (2008). Do large hedgers and speculators react to events? A stability and events analysis. Applied Financial Economics Letters, 1-9.

22. Gurrib, I. (2009). Measurement of large hedgers and speculators risk in major US Futures markets. Journal of Risk, 12(2), 2009/2010 Winter Issue.

23. Guttentag, J. M., \& Herring, R. J. (1986). Disaster Myopia in International Banking, Princeton University. Essays in International Finance, 164(September).

24. Hakkio, C. S., \& Keeton, W. K. (2009). Financial stress: What is it, how can it be measured, and why does it matter? Federal Reserve Bank of Kansas City Economic Review.

25. Hatzius, J. (2010). Financial Conditions Indexes: A Fresh Look after the Financial Crisis (NBER Working Paper Series w16150).

26. Hatzius, J. P., Hooper, F. S., Mishkin, K. L., Schoenholtz, \& Watson, M. W. (2010). Financial Conditions Indexes: A Fresh Look after the Financial Crisis (NBER Working Paper No. 16150). Cambridge, Massachusetts: MIT Press.

27. Hautsch, N., \& Hess, D. (2007). Bayesian Learning in Financial Markets: Testing for the Relevance of Information in Price Discovery. Journal of Financial and Qualitative Analysis, 1(42), March

28. IMF (2014). Global Liquidity Issues for Surveillance (IMF Policy Paper, Washington, DC).

29. IMF (2017). Are countries losing control of domestic financial conditions? (IMF Global Financial Stability Report, Chapter 3, April)

30. Kearns, J., \& Patel, N. (2016). Does the financial channel of exchange rates offset the trade channel? BIS Quarterly Review, December, 95-113.

31. Kliesen, K. L., Owyang, M. T., \& Vermann, E. K. (2012).

Disentangling Diverse Measures: A Survey of Financial Stress Indexes. Federal Reserve Bank of St. Louis Review, September/October 2012, 94(5), 369-397.
32. Klitgaard, T., \& Weir, L. (2017). Exchange Rate Changes and Net Positions of Speculators in the Futures Market. New York Federal Reserve. Retrieved from https://www.newyorkfed.org/medialibrary/media/research/epr/04v10n1/0405klitpdf.pdf (accessed on November 14, 2017).

33. Koop, G., \& Korobilis, D. (2014). A New Index of Financial Conditions. European Economic Review, 71, 101-16.

34. Lo Duca, M., \& Peltonen, T. A. (2011). Macro-Financial Vulnerabilities and Future Financial Stress: Assessing Systemic Risks and Predicting Systemic Events (ECB Working Paper Series No. 1311, EURpean Central Bank). Retrieved from www.ecb.int/pub/pdf/scpwps/ecbwp1311.pdf (accessed on November 15, 2017).

35. Louzis, D. P., \& Vouldis, A. T. (2011) A Financial Systemic Stress Index for Greece. Presented at the First Conference of the Macro-prudential Research (MaRs) network of the EURpean System of Central Banks in Frankfurt am Main, October.

36. Ludvigson, S., \& Ng, S. (2007). The empirical risk - return relation: A factor analysis approach. Journal of Financial Economics, 83(1), 171-222.

37. Montagnoli, A., \& Napolitano, O. (2005). Financial condition index and interest rate settings: $a$ comparative analysis (Money Macro and Finance MMF Research Group Conference Working Paper No 8).

38. Nash, J. E., \& Sutcliffe, J. V. (1970). River flow forecasting through conceptual models part I A discussion of principles. Journal of Hydrology, 10(3), 282-290.

39. Nelson, W. R., \& Perli, R. (2007) Selected Indicators of Financial Stability in Risk Management and Systemic Risk. Frankfurt, Germany: EURpean Central Bank. Retrieved from www.ecb.int/pub/pdf/ other/riskmeasurementandsystemicrisk200704en.pdf

40. Obstfeld, M. (2015). Trilemmas and tradeoffs: living with financial globalization (BIS Working Papers No 480).

41. Pastor, L., \& Veronesi, P. (2008). Learning in Financial Markets
(University of Chicago Business School Working Paper (No. 08-28)).

42. Peek, J., \& Eric S. Rosengren (2000). Collateral Damage: Effects of the Japanese Bank Crisis on Real Activity in the United States. American Economic Review, 90(1), 30-45.

43. Rey, H. (2013). Dilemma Not Trilemma: The Global Financial Cycle and Monetary Policy Independence. Paper presented at Global Dimensions of Unconventional Monetary Policy Symposium, Jackson Hole, WY, August.

44. Schoenmaker, D. (2013). The Financial Trilemma. Economic Letters, 111(1), 57-59.

45. Stock, J. H., \& Mark W. Watson (2002). Forecasting Using Principal Components from a Large Number of Predictors. Journal of the American Statistical Association, 97(460), 1167-1179.

46. Swiston, A. (2008). A U.S. Financial Conditions Index: Putting Credit Where Credit is Due (IMF Working Paper WP/08/161). 